\title{
Expressions of Bradykinin B2-Receptor, Kallikrein and Kininogen mRNAs in the Heart Are Altered in Pressure-Overload Cardiac Hypertrophy in Mice
}

\author{
Katsutoshi Yayama, Hiromi Hiyoshi, and Hiroshi Окамото* \\ Department of Pharmacology, Faculty of Pharmaceutical Sciences and High Technology Research Center, Kobe Gakuin \\ University, Nishi-ku, Kobe 651-2180, Japan. Received August 2, 2000; accepted October 26, 2000
}

\begin{abstract}
Angiotensin-converting enzyme inhibitors prevent cardiac hypertrophy in vivo, and a component of this ameliorative effect has been attributed to accumulation of kinins in cardiac tissues. However, little is known regarding the levels of kallikrein-kinin components in the heart during the development of cardiac hypertrophy. The objectives of the present study were to define the effects of pressure-overload cardiac hypertrophy on cardiac levels of kininogen, kallikrein and bradykinin B2 receptor mRNAs. The pressure-overload induced by aortic constriction produced cardiac hypertrophy in mice after 14 and $28 \mathrm{~d}$, assessed from the increased ratios of heart weight to body weight and elevation of brain natriuretic peptide mRNA in the heart. B2 receptor mRNA rapidly decreased in the heart within $7 \mathrm{~d}$ after the operation, subsequently returning to those of sham-operated animals. In contrast, levels of both low-molecular-weight kininogen and tissue kallikrein mRNAs were increased 7, 14 and $28 \mathrm{~d}$ after aortic constriction. These findings suggest that the mechanical load or stretch in cardiac tissue by pressue-overload rapidly produces the downregulation of B2 receptor expression during the initial stage which may allow the promotion of cardiac hypertrophy induced by a mediation of hypertophic factors such as angiotensin II, while upregulation of kininogen and kallikrein mRNAs during the chronic stage may lead to an enhancement of local kinin generation in the heart, from which further progression of cardiac hypertrophy during later stages may be regulated.
\end{abstract}

Key words cardiac hypertrophy; bradykinin receptor; kallikrein; kininogen; kallikrein-kinin system; mouse

Cardiac left ventricular hypertrophy is most commonly associated with hypertension and is an independent risk factor for cardiovascular events in patients with hypertension. Mechanical load or stretching in cardiac tissue has been identified as a growth stimulus and may be relevant in hypertension-induced cardiac hypertrophy. ${ }^{1)}$ Hormonal stimuli, such as angiotensin II, endothelins, norepinephrine, and thyroid hormone, have also been postulated to play a role in the regulation of cardiac cell growh. ${ }^{2-5)}$ Based on the finding that angiotensin II stimulates protein synthesis of cardiac myocytes $^{6}$ and that angiotensin-converting enzyme (ACE) inhibitor induces regression of cardiac hypertrophy both in experimental animal models ${ }^{7}$ and in hypertensive patients, ${ }^{8)}$ several studies have suggested a crucial role of the renin-angiotensin system locally present in the cardiac tissue in the formation of hypertrophy. ${ }^{9)}$ Indeed, the activation of the cardiac renin-angiotensin system, such as the upregulation of angiotensinogen, ACE and angiotensin II type-1 (AT1) receptor mRNAs, have been demonstrated in association with cardiac hypertrophy. ${ }^{10-13)}$ In contrast to angiotensin II, kinins produced by the kallikrein-kinin system have been postulated to participate in the beneficial effects of ACE inhibitors, because ACE inhibitors prevent the degradation of kinins into inactive peptides by inhibiting kininase II, and B2 receptor antagonist abolished the reduction of cardiac hypertrophy by an ACE inhibitor in the rat aortic-banding model. ${ }^{14,15)}$ Kinins are released from high- and low-molecular-weight kininogens ( $\mathrm{H}-$ and L-kininogens, respectively) by kininogenases such as plasma and tissue kallikreins. ${ }^{16)}$ Evidence suggests that a local kallikrein-kinin system exists in the heart, which enables it to synthesize and release kinins. ${ }^{17)}$ In this respect, we have demonstrated that rat cardiac myocytes express mRNAs for bradykinin B2-receptor, kininogen and kallikrein, supporting the presence of the local kallikrein- kinin system in the heart. ${ }^{18)}$ Recent studies have provided evidence that kinins released locally in the heart may act as autocrine/paracrine hormones, inhibiting the cardiac remodeling process, such as cardiomyocyte hypertrophy and hyperplasia of interstitial fibroblasts, suggesting that kinins are cardioprotective factors inhibiting the progression of cardiac hypertrophy. ${ }^{19-22)}$ In these studies, however, alterations of the cardiac kallikrein-kinin system during the formation of hypertrophy were not investigated. We hypothesized that the cardiac kallikrein-kinin system may be altered during the development of heart failure and may contribute to the pathophysiology of this disease state. Therefore, the present study was designed to answer this question by determining mRNA levels of the kallikrein-kinin components, such as kininogens, tissue kallikrein and bradykinin receptors, during the development of pressure-overload cardiac hypertrophy in mice.

\section{MATERIALS AND METHODS}

Abdominal Aorta Constriction Adult male ICR mice (10 weeks old) obtained from SLC (Shizuoka, Japan) were divided into two groups: the aortic constricted group (49 mice) and sham-operated group (20 mice). Animals of both groups were anesthetized intraperitoneally with $45 \mathrm{mg} / \mathrm{kg}$ of ketamine and $5 \mathrm{mg} / \mathrm{kg}$ xylazine, and the aorta was exposed through a midline abdominal incision. In the experimental animals, a blunted 26-gauge needle was placed adjacent to the abdominal aorta between renal arteries just below renal bifurcations, and a ligature was tightened around the aorta and the adjacent needle. The needle was then removed, leaving the vessel constricted to the diameter of the needle $(0.45 \mathrm{~mm})$. In the sham-operated group, the ligature was not tightened. Four sham-operated and 5-14 aortic constricted 
mice were sacrificed at 2, 4, 7, 14 and $28 \mathrm{~d}$ after operation, respectively, to obtain cardiac samples.

Detection of mRNAs for Kininogen, Tissue Kallikrein and Bradykinin B2 Receptor in Myocardium The animals were killed with ether, then the heart was removed, weighed and placed in $3 \mathrm{ml}$ of acid guanidinium thiocyanate. Total RNA was extracted with acid guanidinium-phenolchloroform from isolated myocardium. ${ }^{23}$ To detect mRNAs for kininogen, tissue kallikrein (mK1) and bradykinin B2 receptor, we used reverse transcription-polymerase chain reaction (RT-PCR) followed by Southern blotting using specific probes, respectively. Primers used in the present study are summerized in Table 1 . Total RNA $(0.5 \mu \mathrm{g})$ was reverse transcribed in a $5 \mu \mathrm{l}$ reaction mixture containing $50 \mathrm{pmol}$ of the reverse primer, $2 \mu \mathrm{l}$ of $10 \mathrm{~mm}$ dNTP, $0.5 \mu \mathrm{l}$ of $10 \times \mathrm{PCR}$ buffer $(0.1 \mathrm{~m}$ Tris- $\mathrm{HCl}$, pH 8.3, $500 \mathrm{~mm} \mathrm{KCl}), 1 \mu 1$ of $25 \mathrm{~mm}$ $\mathrm{MgCl}_{2}$, and 1 unit of cloned Moloney murine leukemia virus reverse transcriptase (GeneAmp RNA PCR kit; Takara, Japan). The RT reaction mixture was incubated at $42{ }^{\circ} \mathrm{C}$ for $15 \mathrm{~min}, 95^{\circ} \mathrm{C}$ for $5 \mathrm{~min}$, then $4^{\circ} \mathrm{C}$ for $5 \mathrm{~min}$ to allow synthesis of the first strand of cDNA. Then, the cDNA was amplified in a $20 \mu \mathrm{l}$ reaction mixture containing $50 \mathrm{pmol}$ of the forward primer, $2 \mu \mathrm{l}$ of $10 \times \mathrm{PCR}$ buffer, $1 \mu \mathrm{l}$ of $25 \mathrm{~mm}$ $\mathrm{MgCl}_{2}$, and 2.5 units of Taq DNA polymerase. Forty cycles for $\mathrm{H}$ - and L-kininogens, and tissue kallikrein), 35 for $\mathrm{B} 2$ receptor or 25 for GAPDH proceeded as follows: denaturation at $94{ }^{\circ} \mathrm{C}$ for $1 \mathrm{~min}$, annealing at $56^{\circ} \mathrm{C}\left(\right.$ H-kininogen), $55^{\circ} \mathrm{C}$ (L-kininogen), $60^{\circ} \mathrm{C}$ (tissue kallikrein and GAPDH), or $58^{\circ} \mathrm{C}$ (B2 receptor) for $2 \mathrm{~min}$ and extension at $72^{\circ} \mathrm{C}$ for $3 \mathrm{~min}$. Then $8 \mu \mathrm{l}$ aliquots were Southern blotted and autoradiographed using a Fuji Film Bio Imaging Analyzer BAS1000 (Fuji Film, Tokyo), as described previously. ${ }^{18)}$ The $\mathrm{H}$ - or L-kininogen cDNAs were used as probes. ${ }^{24)}$ The probe for mouse tissue kallikrein was an oligonucleotide with a sequence of 5'-GGTTGTGGGGTCTGCTCATTCAGGA-3' that corresponded to nucleotides 343-368 of $\mathrm{mK} 1$ mRNA, ${ }^{25)}$ and the B2 receptor was a $417 \mathrm{bp}$ fragment of mouse B2 receptor cDNA obtained by PCR amplification using RNA from mouse heart as a template following TA cloning. ${ }^{26)}$ Although samples from sixty-nine mice were analyzed, data in figures show representative blots from two aortic-constricted and two sham-operated animals per day.

Northern Blots of Brain Natriuretic Peptide (BNP) mRNA in Myocardium BNP mRNA levels in the heart were determined by Northern blotting using a specific probe for mouse BNP mRNA. ${ }^{27)}$

Statistical Analysis Statistical analysis was performed using a one-way analysis of variance (ANOVA). If a significant difference was detected, the individual group difference was examined by Bonferroni's multiple test. A probability value $(p)$ of less than 0.05 was considered to be statistically significant.

\section{RESULTS}

Cardiac Hypertrophy after Aortic Constriction Recently, we demonstrated that rat cardiomyocytes express kininogens, tissue kallikreins and B2 receptor mRNAs, ${ }^{18)}$ but most kininogen mRNAs present in the rat heart was for Tkininogen, which is unique to the rat, suggesting that rat models for cardiac hypertrophy does not appear to be appro-

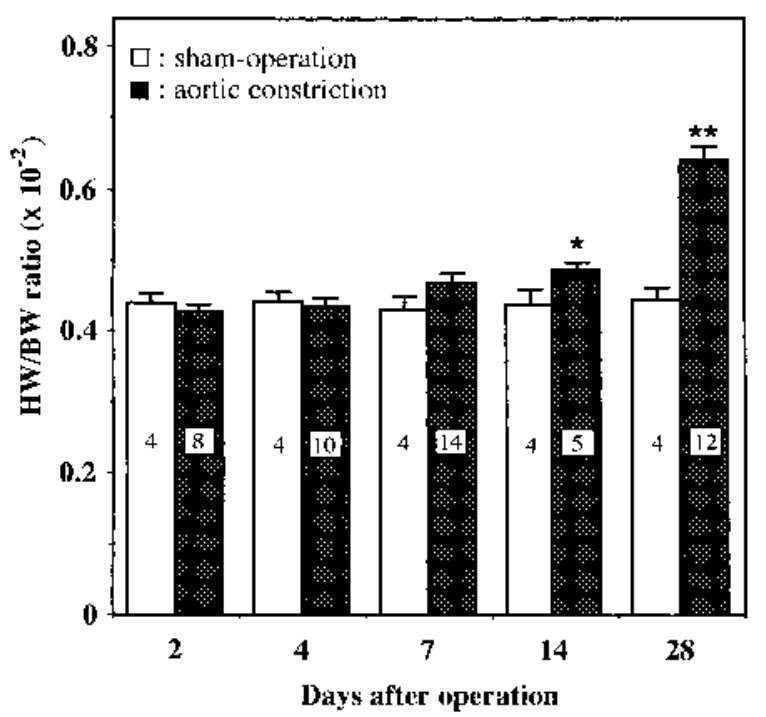

Fig. 1. Heart-to-Body Weight Ratios (HW/BW) of Mice after Abdominal Aortic Constriction

After aortic constriction (closed columns) or sham-operation (open columns), mice were sacrificed at various days shown in the figure and their heart and body weights were measured. Values represent the mean \pm S.E.M. of animals indicated in columns. Aortic-constricted animals were compared with appropriate sham-operated control $(* p<0.05, * * p<0.01)$

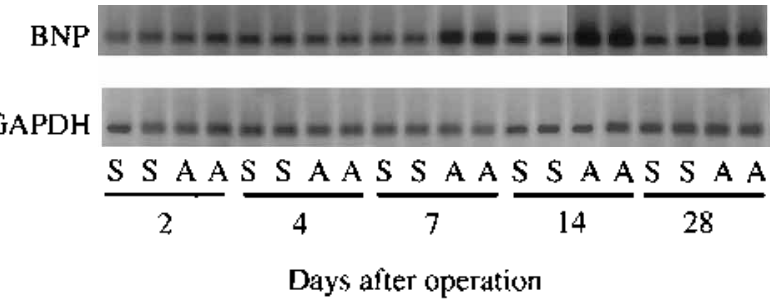

Fig. 2. Representative Northern Blots of Brain Natriuretic Peptide (BNP) mRNA in Mouse Heart after Aortic Constriction

Total RNA samples were prepared from hearts of aortic-constricted (A) and shamoperated (S) animals, then Northern blotting was carried out using mouse BNP cDNA as a probe. Glyceroaldehyde phosphate dehydrogenase (GAPDH) mRNA was determined by RT-PCR followed by Sourthern blotting. Figure shows representative blots from two aortic-constricted and two sham-operated animals per day.

priate to demonstrate the importance of the cardiac kallikrein-kinin system in humans with cardiac hypertrophy. Like humans, mice express only two types of kininogen mRNAs, such as H- and L-kininogens, from a single kininogen gene ${ }^{24)}$ and $\mathrm{B} 2$ receptor in the heart. ${ }^{26)}$ For these reasons, we chose in the present study mouse models for the pressureoverload hypertrophy instead of the rat model usually used. ${ }^{28)}$

The effects of aortic constriction on heart weight to body weight are shown in Fig. 1. Although no significant differences in body weights between sham-operated and experimental animals were observed (data not shown), significant increases in heart weight to body weight ratios were present at 14 and $28 \mathrm{~d}$ after abdominal aorta constriction. Concomitantly with increases in cardiac mass, BNP mRNA levels, a marker for cardiac hypertrophy, ${ }^{29)}$ were elevated at 7, 14 and $28 \mathrm{~d}$ post-operation (Fig. 2), indicating generation of cardiac hypertrophy.

Changes in mRNA Levels of Kininogens, Tissue Kallikrein and Bradykinin B2 Receptor in the Heart after Aortic Constriction Cardiac levels of mRNAs for the kallikrein-kinin components, such as B2 receptor, kinino- 


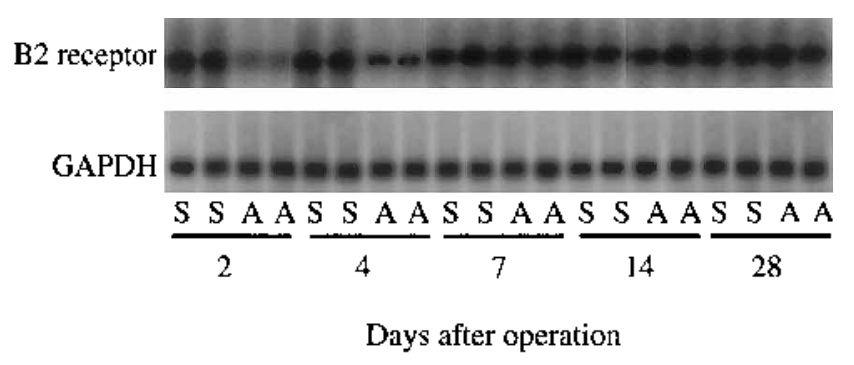

Fig. 3. Representative Sourthern Blots of Bradykinin B2 Receptor mRNA in Mouse Heart after Aortic Constriction

Total RNA samples extracted from hearts of aortic constricted (A) and sham-operated (S) animals were subjected to the RT-PCR using specific primers for mouse B2 receptor cDNA followed by Southern blotting. Figure shows representative blots from two aortic-constricted and two sham-operated animals per day.

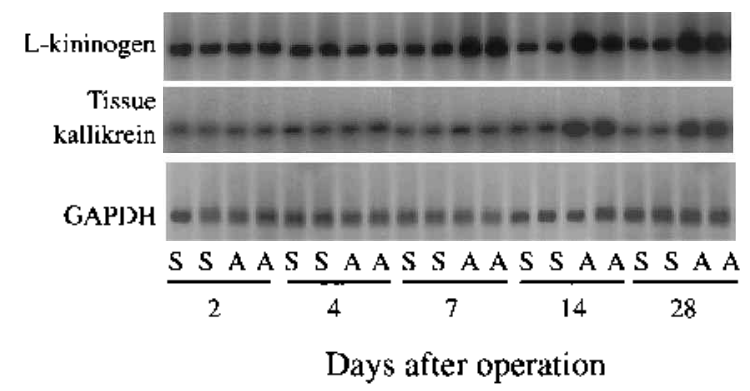

Fig. 4. Representative Sourthern Blots of L-Kininogen and Tissue Kallikrein mRNAs in Mouse Heart after Aortic Constriction

Total RNA samples extracted from hearts of aortic constricted (A) and sham-operated (S) animals were subjected to RT-PCR using specific primers for mouse L-kininogen cDNA or tissue kallikrein (mK1) cDNA followed by Southern blotting. Figure shows representative blots from two aortic-constricted and two sham-operated animals per day.

gens and kallikrein, were detected by RT-PCR following Southern blotting in mice.

Figure 3 shows representative Southern blots of bradykinin B2 receptor mRNA in the heart. No changes in B2-receptor mRNA levels were observed in sham-operated animals after the operation in comparison with non-operated animals (data not shown). However, the aortic constriction caused a reduction of $\mathrm{B} 2$ receptor mRNA levels within $7 \mathrm{~d}$ after the operation; this downregulation of $\mathrm{B} 2$ receptor mRNA was marked at $2 \mathrm{~d}$, slight at $7 \mathrm{~d}$ and was not observed at 14 and $28 \mathrm{~d}$.

Figure 4 shows representative Southern blots of L-kininogen and tissue kallikrein cDNAs amplified from respective mRNAs in the heart by specific primers. Elevations of Lkininogen mRNA levels were observed 7, 14 and $28 \mathrm{~d}$ after aortic constriction. Increased levels of tissue kallikrein mRNA were also present at 14 and $28 \mathrm{~d}$. In agreement with our previous findings, ${ }^{24)}$ no signals corresponding to $\mathrm{H}$ kininogen mRNA were detected in either sham-operated or experimental animals with aortic constriction.

\section{DISCUSSION}

ACE inhibitors are highly effective in the treatment of cardiac hypertrophy within the context of cardiac remodeling. ${ }^{8,30)}$ The precise mechanism by which ACE inhibitors exert their effects on the heart is still unclear, but the presumed mechanism was inhibition of angiotensin II production. However, this notion has been brought into question by
Table 1. Primers Used in This Study

$$
\begin{aligned}
& \text { H-kininogen: Upper 5'-CAGAGCTGTACCCTTATTCA-3' } \\
& \text { l. Gwer S'-GGTGATTCTTATTAGCCFTGA-3' } \\
& \text { L-kiningen: Upper 5'GAGCTGGCAGAAGATTGTGAG 3' } \\
& \text { Lower 5'-GGCACAACACCTCTCCAAACA-3. } \\
& \text { Tissue kallikrein: Ipper 5'-CCCACTGCCATAATGACAAG-3' } \\
& \text { I.ower 5'-GGAGCICATCIGGGIATICA-3' } \\
& \text { B2 receptor: Upper } 5 \text {-ACCICCLCCITCTCCTATCCO- } \\
& \text { Lower 5'-GGCACAACACCTCTCCAAACA-3' }
\end{aligned}
$$

Glyceraldehyde phosphate dehydrogenase (GAPDWH) :

UpPer 5 -GAGCCAAACGGGTCATCATCT-3'

Lower 5 -CGGCATCGAAGGTGGAAGAGT-3'

the observation that another enzyme in the human heart has the capacity to convert angiotensin I to angiotensin II, a chymase that is insensitive to ACE inhibitors. ${ }^{31)}$ In addition, beneficial effects of ACE inhibitors on cardiac remodeling have been found to be blocked by a B2 receptor antagonist, suggesting that elevated tissue levels of kinins play a crucial role in blocking the induction of hypertrophy. ${ }^{19-21)}$ The concept that bradykinin may play an important role in the cardiovascular functions and in the pathogenesis of cardiovascular diseases in humans gained further credence from the observations that chronic ACE inhibitor treatment increases circulating and/or tissue kinin levels but does not produce sustained inhibition of angiotensin II levels. ${ }^{32,33)}$ Although recent findings on the beneficial effects of AT1 receptor antagonists on heart failure further confirmed the essential role of angiotensin II in the development of cardiac hypertrophy, subsequent evidence has suggested that the therapeutic effect of AT1 receptor antagonist is mediated, at least in part, by AT2 receptor activation, ${ }^{34)}$ which in turn releases of autacoids such as kinins and nitric oxide. ${ }^{35)}$ Thus, it is important to understand the relevant functions of the kallikrein-kinin system locally present in the heart with respect to the understanding of not only molecular events in the progresssion of cardiac hypertrophy but also pharmacological actions of ACE inhibitors and AT1 receptor antagonists.

In the present study, we found, for the first time, that B2 receptor mRNA was downregulated during an initial stage of pressure-overload hypertrophy, while tissue kallikrein and Lkininogen mRNAs were upregulated during the later stage. In view of the postulated role of kinins as an antihypertrophic factor, the decreased expression of $\mathrm{B} 2$ receptors in the heart is considered to be one of the compensatory mechanisms in the face of a rapidly increased workload that may lead to the reduction of transduction signals of kinins via these receptors which allow the promotion of angiotensin II-mediated hypertrophic signals. The in vitro study has demonstrated that bradykinin abolished the angiotensin II-induced hypertrophy in rat cardiomyocytes cocultured with non-myocytes, and suggested that bradykinin inhibits angiotensin II-induced hypertrophy by releasing some paracrine mediators from nonmyocytes in intact hearts. ${ }^{36}$ ) Thus, the downregulation of B2 receptor during the initial stage of pressure-overload may be 
one of the compensatory mechanisms required for the cardiac adaptation to a rapid increase in cardiac load. However, since mRNA levels are not always reflected by protein levels, it will be important in further studies to confirm the downregulation of $\mathrm{B} 2$ receptor proteins using an appropriate technique, such as receptor binding assay.

We detected L-kininogen mRNA as well as tissue kallikrein mRNA in the mouse heart. There are two types of kininogens in mammals, H- and L-kininogens that are endogenous substrates for plasma kallikrein and tissue kallikrein, respectively. ${ }^{16)}$ Mouse L-kininogen liberates braykinin by tissue kallikrein $\mathrm{mK} 1,{ }^{37)}$ instead of lysbradykinin in humans. ${ }^{16)}$ Thus, detection of both L-kininogen and tissue kallikrein mRNAs in mouse heart suggests that there is an intracardiac kinin-generation system in the mouse heart. However, it is currently unknown whether the heart is a source of kininogen, because there is no evidence that myocytes and/or non-myocytes in heart actually synthesize and secrete kininogen proteins. Although L-kininogen mRNA can be demonstrated in the mouse heart, its cardiac levels are very low compared with those in the liver. ${ }^{24)}$ Thus, it cannot be excluded that the kininogen, responsible for cardiac kinin generation, originates from the liver and reaches interstitial spaces of the heart via the circulation. In contrast to kininogen, tissue kallikrein is essentially absent in the circulation, and several endogenous inhibitors for tissue kallikrein are present in plasma. ${ }^{16)}$ Therefore, plasma is not a source of tissue kallikrein in the heart. It is well documented that the tissue kallikreins are a family of serine proteases known for their high degree of sequence conservation but have a diverse range of enzymatic functions. ${ }^{16)}$ The mouse kallikrein gene family includes more than 20 members, of which tissue kallikrein designated as $\mathrm{mK} 1$ cleaves L-kininogen to release bradykinin. ${ }^{38)}$ To determine mRNA levels of tissue kallikrein corresponding to $\mathrm{mK} 1$, we used a set of primers that corresponded to nucleotides $221-240$ (upper primer) and nucleotides 525-544 (lower primer) of mK1 mRNA, and amplified a $325 \mathrm{bp}$ fragment from mK1 cDNA, because these primers appeared to be more specific for $\mathrm{mK} 1$ than other mouse kallikrein family members. ${ }^{25)}$ Although we have no evidence whether cDNAs from other kallikrein family members contaminated in amplified products, it appears likely that major signals in Southern blotting represent those corresponding to mK1 mRNA.

In the present study, we found that, 2 to 4 weeks after aortic constriction, B2 receptor mRNA levels were normalized, and expressions of L-kininogen and tissue kallikrein mRNAs were increased. Although it is unclear whether the elevation of L-kininogen mRNA in heart has the physiological relevance described above, elevation of tissue kallikrein mRNA levels implies that there is an activation of kinin-generation system in the heart during later stages of pressure-overload hypertrophy. During these stages, the progression of hypertrophy appears to be determined by a balance between various hypertrophic factors and antihypertrophic factors; a major hypertrophic factor is believed to be angiotensin II which is derived from the upregulation of the cardiac reninangiotensin system. ${ }^{10-13)}$ In view of the postulated role of kinins as an antihypertrophic factor, upregulation of the cardiac kallikrein-kinin system observed during the later stage appears to be associated with regulating further progression of hypertrophy.

The exact stimuli for the downregulation of cardiac B2 receptor mRNA are unclear. Mechanical stress or pressure overload in vivo are known to induce the expression of a number of immediate-early genes, such as $c$-fos, $c$-jun, $c$-myc and Egr- $1,{ }^{39)}$ thereafter, the expression of $\beta$-myosin heavy chain, atrial natriuretic peptide and smooth muscle $\alpha$-chain as well as the downregulation of the sarcoplasmic reticulum $\mathrm{Ca}^{2+}$-ATPase. ${ }^{40)}$ In addition to these genes, upregulation of angiotensinogen, ACE and AT1 receptor mRNAs in the heart has been described in association with cardiac hypertrophy, ${ }^{10-13)}$ and thus angiotensin II locally generated in the heart has been suggested to be a critical factor promoting the growth of cardiac myocytes by autocrine or paracrine mechanisms. Interestingly, upregulation of AT1 receptor mRNA is also observed in cultured cardiomyocytes after mechanical loading. ${ }^{41)}$ Thus, it is presumed that mechanical stress induced by pressure overload directly or by a mediation of some factors rapidly downregulates expression of the cardiac B2 receptor gene after pressure overload. However, the present findings are informative for the situation specific to a mouse model for pressure overload and for the mRNA levels of the kallikrein-kinin components. Whether locally produced kinins are negatively contributing to the cardiac hypertrophy that develops in this model is not known at present. Further studies will be directed toward determining the cellular localization and levels of the kallikrein-kinin components in the hypertrophied heart and the physiological role of an intracardiac kallikrein-kinin system in the development of cardiac hypertrophy.

Acknowledgements This study was supported, in part, by Grants-in-Aid from the Ministry of Education, Science, Culture and Sports of Japan and a grant from Kobe Gakuin University for Medical Science Research.

\section{REFERENCES}

1) Komuro I., Yamazaki Y., Annu. Rev. Physiol., 55, 55-75 (1993).

2) Sadoshima J., Izumo S., Circ. Res., 73, 413-423 (1993).

3) Ito H., Hirata Y., Adachi S., Tanaka M., Koike A., Nogami A., Muruno F., Hirose M., J. Clin. Invest., 92, 398-403 (1993).

4) Simpson P., Circ. Res., 56, 844-894 (1985).

5) Carter W. J., van der Weijden Benjamin W. S., Faas F. H., J. Mol. Cell. Cardiol., 17, 897-905 (1985).

6) Baker K. M., Aceto J. F., Am. J. Physiol., 259, H610-H618 (1990).

7) Linz W., Schaper J., Wiemer G., Albus U., Scholkens B. A., Ganten D., Br. J. Pharmacol., 107, 970-975 (1992).

8) Sharpe N., Murphy J., Smith H., Hannan S., Lancet, 1, 255-259 (1988).

9) Pfeffer J. M., Fischer T. A., Pfeffer M. A., Annu. Rev. Physiol., 57, 805-826 (1995).

10) Schunkert H., Dzau V. J., Tang S. S., Hirsch A. T., Apstein C. S., Lorell B. H., J. Clin. Invest., 86, $1913-1920$ (1990).

11) Suzuki J., Matsubara H., Urakami M., Inada M., Circ. Res., 73, 439447 (1993).

12) Lindpaintner K., Wenyan L., Niedermajer N., Schieffer B., Just H., Ganten D., Drexler H., J. Mol. Cell. Cardiol., 25, 133-143 (1993).

13) Hirsch A. T., Talsness C. E., Schunkert H., Paul M., Dzau V. J., Circ. Res., 69, 475-482 (1991).

14) Linz W., Scholkens B. A., Br. J. Pharmacol., 105, $771-772$ (1992).

15) Scicli A. G., Hypertension, 23, 419-420 (1994).

16) Bhoola, K. D., Figueroa C. D., Worthy K., Pharmacol. Rev., 44, $1-80$ (1992)

17) Nolly H., Carbini L. A., Scicli G., Carretero O. A., Scicli A. G., Hypertension, 23, 919-923 (1994). 
18) Yayama K., Nagaoka M., Takano M., Okamoto H., Biochim. Biophys. Acta, 1459, 69-77 (2000).

19) Linz W., Scholkens B. A., J. Cardiovasc. Pharmacol., 20, S83-S90 (1992).

20) Martorana P. A., Kettenbach B., Breipohl G., Linz W., Scholkens B. A., Eur. J. Pharmacol., 182, 395-396 (1990).

21) Hartman J. C., Hullinger T. G., Wall T. M., Shebuski R. J., Eur. J. Pharmacol., 234, 229-236 (1993).

22) Ishigai Y., Mori T., Ikeda T., Fukuzawa A., Shibano T., Am. J. Physiol., 273, H2659-H2663 (1997).

23) Chomczynski P., Sacchi N., Anal. Biochem., 162, 156-159 (1987).

24) Takano M., Kondo J., Yayama K., Otani M., Sano K., Okamoto H., Biochim. Biophys. Acta, 1352, 222-230 (1997).

25) van Leeuwen B. H., Evans B. A., Tregear G. W., Richards R. I., J. Biol. Chem., 261, 5529-5535 (1986).

26) McIntyre P., Phillips E., Stkidmore E., Brown M., Webb M., Mol. Pharmacol., 44, 346-355 (1993).

27) Ogawa Y., Itoh H., Tamura N., Suga S., Yoshimasa T., Uehira M., Matsuda S., Shiono S., Nishimoto H., Nakao K., J. Clin. Invest., 93, 1911-1921 (1994).

28) Doggrell S. A., Brown L., Cardiovasc. Res., 39, 89-105 (1998).

29) Yasue H., Yoshimura M., Sumida H., Kikuta K., Kugiyama K., Jougasaki M., Ogawa H., Okumura K., Mukoyama M., Nakao K., Circulation, 90, 195-203 (1994).

30) Brunel P., Agabitirosei E., Clin. Drug Invest., 12, 226-243 (1996).
31) Urata H., Healy B., Stewart R. W., Bumpus F. M., Husain A., Circ. Res., 66, 883-890 (1990).

32) Baruch L., Anand I., Cohen I. S., Ziesche S., Judd D., Cohn J. N., Circulation, 99, 2658-2664 (1999).

33) Zisman L. S., Circulation, 98, 2788-2790 (1998).

34) Zhu Y. C., Zhu Y. Z., Gohlke P., Stauss H. M., Unger T., Am. J. Cardiol., 80, A110-A117 (1997).

35) Tsutsumi Y., Matsubara H., Masaki H., Kurihara H., Murasawa S., Takai S., Miyazaki M., Nozawa Y., Ozono R., Nakagawa K., Miwa T., Kawada N., Mori Y., Shibasaki Y., Tanaka Y., Fujiyama S., Koyama Y., Fujiyama A., Takanashi H., Iwasaka T., J. Clin. Invest., 104, 925935 (1999).

36) Ritchie R. H., Marsh J. D., Lancaster W. D., Diglio C. A., Schiebinger R. J., Hypertension, 31, 39-44 (1998).

37) Sueyoshi T., Uwani M., Itoh N., Okamoto H., Muta T., Tokunaga F., Takada K., Iwanaga S., J. Biol. Chem., 265, 10030-10035 (1990).

38) Evans B. A., Drinkwater C. C., Richards R. I., J. Biol. Chem., 262, 8027-8034 (1987).

39) Turner C. E., Glenney J. R., Burridge K., J. Cell Biol., 111, 10591068 (1990)

40) Parker T. G., Schneider M. D., Annu. Rev. Physiol., 53, 179-200 (1991).

41) Kijima K., Matsubara H., Murasawa S., Maruyama K., Mori Y., Ohkubo N., Komuro I., Yazaki Y., Iwasaki T., Inada M., Circ. Res., 79, 887-897 (1996). 